\title{
EAST - WEST VERSUS THE WEST - THE REST
}

\begin{abstract}
The text begins from the perception and reception of the globalist or anti-globalist processes over the past 20 years, which have led to a massive growth of the economic, political, and military power of some new (or re-strengthening of some old) world powers, such as for example Russia, China, Turkey, Iran, India, Brazil and other. Based on the new reality of the world economic, geopolitical and cultural "map", the text gives arguments for the obsolescence of traditional civilization, cultural and general "axiological" conceptual-categorical division to East and West, and all stereotypes, misconceptions and prejudice to that division, placed primaryly by the powerful western media propaganda machine for the past two centuries. The brutal and bloody struggle for the preservation of its own hegemonic and dominant position of the imperial and postcolonial forces (predominantly highly developed capitalist states of the EU and NATO, headed by the United States) and their treatment of all others as a postcolonial "rest of the world" gives the right to all those analysts of a variety of philosophical, scientific and theological provenance, which the West and the Rest phrase consider to be the most accurate conceptual-categorical "reflection" of the new world reality.

For truth's sake, this phrase becomes more evident with and unavoidable in the field of research and activity of such an important science and practice of human existence today - bioethics.
\end{abstract}

Keywords: EAST, WEST, REST, CIVILIZATION, BIOETHICS

\section{History means interpretation}

Edward Hallett Carr

In the form of synopsis, or short consecutive thesis, we will try to answer several questions, including the necessary simplifications that are in such cases inevitable:

1. We will try to date the divisions to East and West based on historical artefacts, i.e. based on the facts of the written, memorized history;

2. We will make a "jump" in the present, i.e. in the modernity of the $20^{\text {th }} / 21^{\text {st }}$ century, and we will start from the problematization of this axiological, conceptual-categorical division only in several contempo- 
rary authors (listed in the Bibliography!) which - according to our modest assessment - most objectively reflect this division;

3. We will problematize this division in the current new geopolitical divisions in the multipolar/polycentric and multicultural/multilateral world, namely we will locate the new division: The West and The Rest;

4. Finally, we will come to bioethics, which is the reason and the cause of our meetings, ${ }^{1}$ and its application and multiplication beyond these old and new "block" divisions; and ...

5. In the end, but no less important, we will also touch one aspect, which, according to the titles of the proposed abstracts of this Conference, ${ }^{2}$ is little represented, or not at all, and that is the gender aspect of bioethics, i.e. bioethics seen through the prism of the genre strategies.

Let's take a turn:

First, we do not mention the invading wars of Alexander the Great in the East, because then there was no developed civilization and culture in the West. It was in Ancient Rome when this division began to be historical and conceptually relevant, in particular with the division to Eastern and Western Roman Empire, i.e. later Byzantium, and the small Balkan reigns that were born at the time of its decline and decay. Schism of 1054 reinforces this EastWest division, and until today, on different grounds, establishes and maintains the difference between Eastern, Orthodox and Western, Catholic/ Protestant church. Although the formal centre of Orthodoxy is in Constantinople/Istanbul, it is logical that the largest and most powerful Orthodox Church is the Russian Orthodox Church. Moreover, we must continually recall that Christianity itself was born in the East/Middle East, (today we would say on the Orient), and then spreads to the West, namely to Rome, and then far in the same direction over the Atlantic in South and North America, but only after Christopher Columbus, that is, from the 16th century to the present. It is similar with the proliferation of Islam, which established a new stereotyped antipode to the Orient (-alism) and Occident (-alism), which persists to date, and at all levels: economic, geopolitical, ideological, scientific, gene-

\footnotetext{
${ }^{1}$ It is about the International Conference 4th International Philosophical Dialogue «EAST-WEST», symposium on the subject "Bioethics on crossroads", which was held in Skopje, Bitola and Ohrid (Republic of Macedonia), in the period from 3rd to 5th October, 2018,organized by the Slavic University "G.R. Derzhavin", the Macedonian Academy of Sciences and Arts (MANU) and the Philosophical Society of Macedonia (FDM).

${ }^{2}$ The complete program of the conference to which the author is referring is available at: http://konferencii.msu.edu.mk/wp-content/uploads/Programa-East-West-2018-FINAL.pdf (Editorial note).
} 
ric, cultural, religious, military-strategically (!). (Саид, 2003; Hobson, 2004; Hobson, 2012). In the latest conceptual-categorical classifications, for example, within the Critical Theory and its followers, it is said about the division of societies and cultures to modern (read: Western), and pre-modern (read: The Rest). (Allen, 2015)

At a lower level, we would say the level of political anthropology, during the $19^{\text {th }}$ and $20^{\text {th }}$ centuries, a single and collective awareness of themselves as a separate ethos of the Western liberal, progressive and democratic civilization is differentiated, unlike the east as eternal "Despotic" and "totalitarian", backward and conservative. (Allen, 2015) This anthropological ideological "model" or "profile" of a man (man/woman) is constantly threatened by the "enemy", which, of course, always comes "from the East", and who in the collective personification of Barbarians, atheists, primitives, evildoers, criminals, and other savages, is a constant "threat" to the fate of the Western man (Стејс, 1991; Todorov, 2010). This "model" of Man - with its mind, reason and virtue - through the course of world history has always proven to be civilizational and culturally superior to the others, i.e. The rest. (Ferguson, 2012; Џепароски, 2007; Кокер, 2006) Examples of such "state of the spirit" or conditio humana in Western philosophy, science and art, but also the honest attempts at its dialectical overcoming (Hegel would say Dialectische Aufhebung) we have quite a lot, but they are mostly silent, or their works on this subject are "forgotten." (Остен, 2005) We can begin with the brilliance of Johann Wolfgang Goethe, and through Oswald Spengler, to finish with Aleksandar Dugin (Goethe, 1966; Spengler, 1998; Дугин/Савин, 2018). But given that it is about outstanding thinkers who deserve a thorough review, we decided to quote the modern Austrian politician and theorist, Erhard Busek, in his book "The Open Gate to the East," which summarizes these Western-Eastern value paradigms:

In the opera "Loengrin" by Richard Wagner, the emperor collects the military before a military campaign and announces: "The kingdom is threatened from the East." It seems to have been a permanent feature of the German experience of themselves, given that modern-day Austria is branded in the East, and in the millennium as an "Eastern mark" (Ostmark). (...) The term "Balkanization" has long been common, but similar terms exist in relation to Russia and Turkey, as with all other countries, which are evidence of huge uncertainty, which is, among other things, a consequence of ignorance. (Underlined by - D.S.) (...) With the movement of the EU's external borders to the east, the simple division to the West and the East, as provided by the "Iron Curtain," went into disrepair. The very widespread ignorance of these countries is no longer an argument for putting them in the ranks of "Eastern countries". (Underlined by - D.S.)

(Busek, 2007, p. 15-16, 67,61) 
The modern contemporary of Busek, Austrian diplomat Wolfgang Petritsch, in the newspaper Nova Makedonija (September 10, 2015) declares that "the majority in Europe, both the states and the citizens, understand that the name issue (Macedonia - NB of D.S.) is a scandalous behaviour by one Member State". (Greece - NB of D.S.) Actually, I personally think that the name "Republic of North Macedonia" is a product of political genetic engineering, or, maybe we would say - bioethical genetic engineering?!

The above statements give us a cue to our Second abstract-thesis with which we enter directly into the $20^{\text {th }}$ and $21^{\text {st }}$ century. We proceed from the analyses of the contemporary Swiss cultural philosopher Elmar Holenstein. As a major and chronic problem in defining the terms East and West, Holenstein stresses the problem of defining European borders, i.e. their alignment with borders of EU member states, which is a total nonsense, above all compared to countries that transcend European borders from West to East, such as Russia, and from the East to the West, such as Turkey, which become key countries in the huge Eurasian belt from Lisbon to Vladivostok. (Holenstein, 1998; Зиновјев, 2002; Давутоглу, 2013; Скаловски, 2010) It is known that Charles de Gaulle, during his long and controversial military and political career, is in fact the main creator of the European Union, no matter what his famous statement on "Europe from the Atlantic to the Urals" even until today has been variously interpreted. Wanting to distance himself from the United States and from the (then) Soviet Union, in his "definition" of the European borders, most explicitly put Russia in, adding with that additional dilemmas: geostrategic, economic, political, cultural, axiological, confessional, ideological, etc., and which last until today.

These dilemmas are even more actualized in recent years, when European unity and the future of the EU are seriously questioned, for a variety of reasons, but in which dominate those that Busek insists on. This is the elementary ignorance of a number of civilizations and cultures in the East, which led to the formation of false representations, negative myths, ideological fictions, stereotypes and prejudices to the extent of mass anxiety, schizophrenia and hysteria, effectively placed through global media, and their role in the control of thought in democratic societies. (Чомски, 2003; Дугин/Савин, 2018) With the termination of the existence of the Eastern Bloc and the Soviet Union, the EU and NATO are losing the power and sense of their existence and geostrategic feasibility (its raison d'etre), regardless of the numerous conceptual creators and visionaries of EU had human, moral and peaceable intentions (from Immanuel Kant, through Edmund Husserl, to Jürgen Habermas), primarily in the interest of the citizens of Europe, i.e. "ordinary people", (simple human beings).

However, these hopes not only did not materialize - what Habermas himself conclusively states - but by equalizing the EU space with NATO space, came to additional homogenization of a geographical area of highly de- 
veloped capitalist countries, both European (EU) and Atlantic (USA and Canada), are distancing themselves and closing in a world that is self-identifiable as Western. (Habermas, 2014, Зиновјев, 2002) This world, or community - despite the heterogeneity and strengthening of the centrifugal forces within itself - towards the outside, i.e. towards other parts of the world, acts as with a remnant, namely (mal-)treats it as the Remnant of the Planet.

Additional internal cracks in that Western world are inserted by the latest moves of Donald Trump, who, with his explicit intention of abolishing the financing of the European wing of NATO by the United States, introduces additional confusion, uncertainty and schism in the already confused and crisis system of Western values, norms and paradigms: economic, legal, political, cultural, confessional, and their normative hierarchy. It fails because of inability to meet the material/ profit interests of different sides, primarily of the national and transnational world elites, which more and more are necessarily mutually confronting. (The most recent example is the confrontation of Donald Trump with Emanuel Macron at the General Assembly's meeting on September 26, 2018. So, it is about intra-confrontations (within the European, and then in the Euro-Atlantic capitalist establishment), and inter-confrontations, namely confrontation with the rest of the world, which gets more "capitalized" and reacted with laughing to the performance of Donald Trump. However, this performance was not a mockery, because it was certainly in the interest of the American people, because that people have a priority in Trump's policy, which is certainly the most logical and the most legitimate.

This already takes us deeply into the third issue of our paper, namely the relationship of this inwardly disunited Western world to the rest of the world, as called by Nial Ferguson, and which is also a world of internal divisions and confronted interests, above all economic, hence it means a world of polycentric, multicultural and multiconfessional spheres of influence, or "attractive gravitational fields," as Erhard Busek calls it, and which, as we said, the traditional division of the East and the West, makes it anachronistic and pointless. (Ferguson, 2012; Busek, 2007) It seems as though we are approaching a situation that Thomas Hobbes popularly defined as a "war of all against all" (bellum omnium contra omnes), but this time not only on national but also on international, or global level.

On the other hand, the new global reality shows a high degree of mutual interdependence, interaction, mutual familiarity and openness - starting from climate change and ending with global trade - which altogether prevents any isolation or self-isolation and autarchy of the strongest economies and economic unions, like the $\mathrm{EU}$ in its beginnings (such as the European Economic Community), or imposing any sanctions on anyone (economic war), and them not being - at their own harm. Let's be reminded that Macron has attacked Trump, among other things, because of the US withdrawal from the Paris Agreement on Climate Change, and climate 
change and its impact on human life and health and global biodiversity are one of the major global challenges, including bioethical/biomedical. (Остен, 2005)

Indeed, sincere, objective and honest analysts and actors of "Western" alliances openly admit that the Western, Euro-Atlantic Alliance has never become a Community for the simple reason that as an artificial creation, it never had common interests, except those during the "cold war" because of the danger of "Russian expansion", which was much more of an invented propaganda as "Bogeyman" than a real danger from the East. (It is a public secret that even during the Cold War, for example, the French industry, exported more than $20 \%$ of its products to the "Eastern Block", namely the Soviet Union!) Today's events inside that "Western Community" are confirming that best, with the difference that today from the fictional story of the Russian "Bogeyman" not even the young children are afraid. Simply, the "enemy" from the East has self-abolished and it is the great headache of those who are struggling to invent a new dangerous and powerful "enemy", of course, again from the East. (Кокер, 2006) It is quite in the spirit of the wellknown Voltaire's slogan: "If God does not exist we should invent it," which transcribed for our context could read: "If Russia did not exist, the West would have invented it." In this way, the serious analysts and strategists are concerned that the West will survive the demise of this fictional enemy, who however kept it "on a pile" for so long and only delayed its deconstruction, its own definite and inevitable civilizational and cultural sunset. (Spengler, 1998; Cocker, 2006) In fact, any economic competitor that would imperil any other economic supremacy and domination/ hegemony of the West through the mediation of sophisticated and media placed ideological/ cultural mechanisms - is declared the enemy. It is indicative that probably the new big "enemy" from the East will be - China!? (Скаловски, 2018)

And the truth is exactly the opposite, and in the spirit of the famous slogan "Hold the thief". Namely, they (the West!) do so to justify their own penetration and expansion towards the East, which is essentially an old and famous strategy, in German called Drang nach Osten! (Drive to the East!), which aims to colonize the Slavic and other Orthodox and Muslim peoples, and to dominate with the great Eurasian natural/ human resources necessary for the further survival and prosperity of Western capitalist imperialism. (The further elaboration of this geostrategy is not a topic of this text, and we leave it for some other occasion!) (Забијакин Чатлеска, 2018)

So, the world not only does not have the interest and need of socioeconomic and social-political communities and military alliances, such as (were!) EU and NATO, but they will be an obstacle and a brake on new bilateral and multilateral relations of the countries which are currently members of these unions, or intend to become their members (namely the Republic of Macedonia). Unfortunately, these associations still manifest egocentricity 
(euro centricity), arrogance, militant secularism, perfidy and hypocrisy, politics of strength, double standards and division into "us" and "others", "civilized" and "barbaric." They are not yet truly ready for equal dialogue with different civilizations and cultures and recognition of their interests, mutual recognition of individual and collective identities (dispute Macedonia $\leftrightarrow$ Greece) and re-evaluating and interpreting the history of Europe, the United States and the "rest" of the world, in which they certainly put Macedonia. (Hobson, 2004; Hobson, 2012; Todorov, 2010; Тодорова, 2001; Кокер, 2006; Џепароски, 2016; Џепароски, 2007)

But from these high and general abstractions and global processes let us descend to the specific, distinct and individual, ordinary human beings, which we have already mentioned, and whose part we are here too, on this inspiring international scientific and cultural event, in the spiritual capital of Macedonia - Ohrid. By this we come to the fourth and most important question for us: the application and multiplication of our own, let's call it a bioethical cause, in this world which is so heterogeneous, complex, multilevel, multidimensional, variable, dynamic, full of differences, but also similarities, compatibilities, contradictions, opposites, twists, which together make it cruelly conflicting. My esteemed colleagues Muzur and Rinčić are helping me in reaching the conclusion:

Bioethics is not an "objective" evidence-based discipline: not only different authors define it differently, but incorporate their own experience, attitudes and world views into it. That makes bioethics intriguing and diverse as not so many areas of thoughtful action. (Underlined by - D.S.)

(Muzur, A/Rinčić, 2018, 171)

But this conclusion as much as helps, it also hinders us, because it not only re-actualizes old, "traditional" philosophical issues and dilemmas (ontological, gnoseological/epistemological, ethical, cultural, ideological), but opens up new without answering the old ones?! However, bioethics is certainly a new challenge and temptation for the philosophical mind and its discursive ethical/moral reflection, no matter that, basically, it wants to give a new answer to the old ethical question: What should I do?, but in the socialontological new circumstances of one - at the same time a constructive and (auto)destructive - technological civilization. In this and such social setting, bioethics - and social philosophy in general - have the duty and responsibility to provide answers to a range of questions, starting from how computers and digital civilization affect the brain functioning of children from an early age and the development of the power of rational reasoning (Chomsky, 1972) and ending with the question of how these children (male/female) when they grow up as responsible moral subjects will be able to survive and prosper in an "objective", profitable world?! This "Brave New World" 
(Huxley), is controlled by a criminal computer system and global network wars are fought, fictitious or realistic, and where different global/regional "world views" are promoted, and conflict geopolitics is led. (Jonas, 1984; Скаловски, 2005; Honneth, 1994; Дугин/Савин) Finnaly, we must not forget that many of these children of the future will be born via surrogate mothers. (Donev, 2019)

According to my personal experience - based on the conceptual-categorical inter-placement and contradiction West-East Versus West-Remainder - Bioethics is an ethics of resistance and an alternative to the suicide path after which one militant civilization has set out, which on the basis of all previous relativizations we can call the Western, and which as such threatens to pull into the abyss the rest of the world. (Видојевић, 2015) In order to be established and constituted as a new ethics, bioethics must first establish a different philosophical/ethical, ontological fundus on the line of totality: nature $\rightarrow$ society $\rightarrow$ state. This consecutive line must return to its existential horizontal rather than current essential vertical, which means first the relationship man $\rightarrow$ man, and then the relationship man $\rightarrow$ God. At first social existence, then metaphysical essence. The world as a whole, the Balkans separately, and Macedonia alone, will still be exposed to new bioethical temptations, which are not God given, but humanly added: starting from the impact of climate change, experimenting with human genes, and through the consequences of shelling with bombs with depleted uranium and the impact on human health, mostly women and children, and so to the refugee camps, which the EU and NATO are planning to build in the Republic of Macedonia. These camps will be "temporarily" accommodated by thousands of people, including children and women, who will want to exercise their legitimate human right, among others - and give birth to children. Of course, we can consider these plans as ordinary spins and insinuations that have become commonplace in the contemporary media war with information and misinformation in the large digital Tower of Babel, but if they prove to be correct, this will mean that we will have many problems, challenges, controversies and temptations for humanism, philanthropy, solidarity, bioethics and gender-bioethics (for example: surrogate motherhood).

This leads to the last, fifth issue, which, because of its importance deserves special analysis and will therefore summarize only a short conclusion: Based on the titles of the papers I do not see that this Conference will pay due attention to generic, gender-aspect. This means that bioethical science and philosophy, namely ethics, will in the future have to pay far greater attention to the bioethical issues from a gender perspective, for whose importance, I think, we do not need to argue. (Симоновска/ Скаловски, 2012) 


\section{References}

Allen, A. (2015). The End of Progress: Decolonizing the normative foundations of Critical Theory, New York: Columbia University Press.

Busek, E. (2007). Otvorena kapija ka istoku, Beograd: Clio.

Carr, E., H. (1961/2002). What is History?, University of Cambridge Press/Palgrave Macmillan, Revised edition.

Čomski, N. (1972). Gramatika i um, Beograd: Nolit.

Donev, D. (2019). Surogat (zamjensko) majčinstvo ili treba li se maternica iznajmljivati, Pannoniana, Fakultet za odgojne i obrazovne znanosti, Osijek, vol.3, No.2, (manuscript).

Ferguson, N. (2012). Civilisation: The West and the Rest, New York: New York Times.

Goethe, J. W. (1966). Goethes Werke in zwölf Band, Zweiter Band, West-Östlicher Divan, (s. 9-132), Berlin: Aufbau-Verlag Berlin und Weimar.

Habermas, J. (2014). Zur Verfassung Europas, Ein Essay, Frankfurt: Suhrkamp.

Hobson, M. J. (2012). The Eurocentric Conception of World Politics, New York: Cambridge University Press.

Hobson, M. J. (2004). The Eastern Origins of Western Civilisation, New York: Cambridge University Press.

Holenstein, E. (1998). Kultur-philosophische Perspektiven; Schulbeispiel Schweiz; Europäische Identität auf dem Prüfstand Globale Verständigungsmölichkeiten, Frankfurt/M., Suhrkamp.

Honneth, A. (Hg.) (1994). Pathologien des Sozialen: Die Aufgaben der Sozialphilosophie, Frankfurt/M.,: Fischer Taschenbuch Verlag.

Jonas, H. (1984). Das Prinzip Verantwortung: Versuch einer Ethik für die technologische Zivilisation, Frankfur/M., Insel Verlag.

Muzur, A. \& Rinčić, I. (2018). Bioetička Europa našeg doba: Struje, kormilari, sidrišta, Zagreb: Pergamena, Znanstveni centar izvrsnosti za integrativnu bioetiku.

Spengler, A. G. O. (1998). Der Untergang des Abendlandes, Augsburg: C.H. Beck.

Todorov, C. (2010). Strah od varvara: S onu stranu sudara civilizacija, Beograd: Karpoš.

Видојевић, 3. (2015). Порази и алтернативе: претна пустоши и етика отпора, Београд: Завод за уџбенике.

Давутоглу, А. (2013). Стратешка длабочина: Меѓународната положба на Туризија, Скопје: Табернакул. 
Дугин, А. \& Савин, А. (2018). Мрежни ратови: Аналитички извештај Александра Дугина уз учешће Валерија Куровина и Александра Бовдунова, Београд: Авала прес д.о.о.

Забијакин Чаклеска, В. (2018). Стратешки практики на човечки ресурси Теорија и емпириски показатели, Скопје: Bigoss.

Зиновјев, А. (2002). Запад: Феномен западюамтва, Београд: Naš Dom/L`Age D`Homme.

Kap, Е. Х. (1990). Што е историјата?, Култура, Скопје.

Кокер, К. (2006). Сумрак Запада, Београд: Досије.

Остен, М. (2005). Покрадено памћене: Дигитални системи и разаране културе сећаға, Нови Сад: Светови.

Петрич, В. (2015). Петрич: Германија и Австрија го преземаат Балканот во свои раце, во Нова Македонија, Четврток, 10 септември, 2015, (стр. 2).

Саид, В. Е. (2003). Ориентализам: западни концеепциии за ориентот, Скопје: Магор.

Симоновска, С. \& Скаловски, Д. (2012). Етиката и родот, (Прирачник), Скопје: Филозофски факултет.

Скаловски, Д. (2010). Во прво лице еднина (мал хичен културолочки речник) - Том 1, од Анг. До Култ., Скопје: Аз-Буки / Филозофски факултет.

Скаловски, Д. (2005). Етика на одговорноста (Ханс Јонас), Скопје: Bigoss.

Стејс, В. (1991). Судбината на западниот човек, Скопје: Култура.

Тодорова, М. (2001). Замислувајќи го Балканот, Скопје: Магор.

Чомски, Н. (2003). Нужни ихузии: контрола на мислата во демократските општества, Скопје: Куятура.

Џепароски, И. (2016). Македонската салата во балканската крчма: другост и идентитет, во Култура и книжевност, Скопје: Магор.

Џепароски, И. (ур.) (2007). Аспекти на другоста (Зборник), Скопје: Менора, Евро Балкан. 